\title{
Determination of Some Heavy Metals in Vegetable Samples from Biu Local Government Area, Borno State, North Eastern Nigeria
}

\author{
J. C. Akan, B. G. Kolo, B. S. Yikala, V. O. Ogugbuaja \\ Department of Chemistry, University of Maiduguri, P.M.B 1069, Maiduguri, Borno State, Nigeria
}

Email address:

joechemakan@yahoo.com (J. C. Akan)

To cite this article:

J. C. Akan, B. G. Kolo, B. S. Yikala, V. O. Ogugbuaja. Determinations of Some Heavy Metals in Vegetable Samples from Biu Local Government Area, Borno State, North Eastern Nigeria. International Journal of Environmental Monitoring and Analysis. Vol. 1, No. 2, 2013, pp. 40-46. doi: 10.11648/j.ijema.20130102.11

\begin{abstract}
The concentrations of some heavy metals and anions were determined in vegetable samples (spinach ( $\mathrm{Ama}$ ranth caudatus), lettuce (lactuca sativa), Cabbage (Brassica olemcea) and Onion (Allium cepa) which were freshly harvested within four agricultural locations(Mirnga, Zira, Wangaga and Malang) in Biu Local Government Area, Borno State, Nigeria. Metal concentrations in the vegetable samples were determined using Atomic Absorption Spectroscopy (AAS), while anions were determined by Smart spectrophotometer (model 2000). The results for vegetable samples showed that leaves contained much higher concentrations of heavy metals and anions than roots and stems. The concentrations of $\mathrm{Cr}$ detected in the vegetable samples ranged from 0.23 to $3.22 \mathrm{mg} / \mathrm{kg} ; 0.23$ to $3.43 \mathrm{mg} / \mathrm{kg} \mathrm{Mn} ; 0.23$ to $3.45 \mathrm{mg} / \mathrm{kg} \mathrm{Fe} ; 0.21$ to $3.54 \mathrm{mg} / \mathrm{kg} \mathrm{Ni} ; 0.25$ to $4.56 \mathrm{mg} / \mathrm{kg} \mathrm{Pb} ; 0.87$ to $8.34 \mathrm{mg} / \mathrm{kg} \mathrm{Zn} ; 0.34$ to $5.44 \mathrm{mg} / \mathrm{kg} \mathrm{Cd}$ and 0.21 to $3.22 \mathrm{mg} / \mathrm{kg} \mathrm{Cu}$. These valueswere higher than those recommended by Food and Agricultural Organization (FAO) and the WHO/EU joint limits. The high levels of these heavy metals place the consumers of these vegetable crops grown within the study area at health risk with time unless an urgent step is taken by relevant agencies to address this issue.
\end{abstract}

Keywords: Heavy Metals, Anions, Vegetables, Accumulation, FAO

\section{Introduction}

The consumption of vegetables and fruits as food offer rapid and least means of providing adequate vitamins supplies, minerals and fibre. Vegetables are used as food include those used in making soups or served as integral parts of the main sources of a meal [1]. Bach plants species has its nutritive requirements differing from others. Thus different plants supported by identical solutions will contain varying concentrations of minor and macro elements. Application of industrial effluent decreases the budding and growth rate of vegetables [1]. Leafy vegetables occupy a very important place in the human diet, but unfortunately constitute a group of foods which contributes maximally to nitrate and other anions as well as heavy metals consumption. The excessive application of nitrogen and other inorganic fertilizers and organic manures to these vegetables can accumulate high levels of nitrate and other anions as well as heavy metals. And consequently their consumption by humans and animals can pose serious health hazards. Although some heavy metals such as $\mathrm{Cu}, \mathrm{Zn}, \mathrm{Mn}$ and $\mathrm{Fe}$ are essential in plant nutrition, many of them do not play any significant role in the plant physiology. The uptake of these heavy metals by plants especially leafy vegetables is an avenue of their entry into the human food chain with harmful effects on health [1].

Vegetables act as neutralizing agents for acidic substances formed during digestion [2]. As human activities increases, especially with the application of modern technologies, pollution and contamination of the human food chain has become inevitable. The uptake of heavy metals by plants grown in polluted soils has been studied to a considerable extent $[2,3]$. Heavy metal contamination in vegetables cannot be underestimated as these food stuffs are important components of human diet. Heavy metal contamination of the food items is one of the most important aspects of food quality assurance $[4,5]$. International and national regulations on food quality have lowered the maximum permissible levels of toxic metals in food items due 
to an increased awareness of the risk, these metals pose to food chain contamination [4].

Rapid and unorganized industrialization and urbanization have contributed to the elevated levels of heavy metals in the urban environment in developing countries [6] Heavy metals are non-biodegradable and persistent environmental contaminants which may be deposited on the surfaces and then adsorbed into the tissues of the vegetables. Plants take up heavy metals by absorbing them from deposits on the parts of the plants exposed to the air from polluted environment as well as from contaminated soils [7, 8, 9]. Water contamination by heavy metals in some areas is practically inevitable due to natural process (weathering of rocks) and anthropogenic activities (industrial, agricultural and domestic effluents). Waste water from the industries of mining, electroplating, paint or chemical laboratories often contains high concentrations of heavy metals, including Cadmium $(\mathrm{Cd})$, Copper $(\mathrm{Cu})$ and lead $(\mathrm{Pb})$. These elements, at concentrations exceeding the physiological demand of vegetables, not only could administer toxic effect in them but also could enter food chains, get biomagnified and pose a potential threat to human health $[8,9]$. Heavy metal contamination in agricultural soils from wastewater irrigation is of serious concern due to its implications on human health. Vegetables can absorb metals from soil as well as from deposits on the parts of the vegetables exposed to the air from polluted environments [10].

The modern agricultural practices which employ the use of organic and inorganic fertilizers, pesticides (both herbicides and insecticides) exposes the lands of Biu Local Government of Borno State to heavy Metal which bioaccumulate as a result of continuous application to the Arable lands.

\section{Materials and Methods}

\subsection{Sample Collection}

Vegetable samples were collected from four agricultural locations (Mirnga, Zira, Wangaga and Malang) within Biu Local Government Area, Borno State, Nigeria. At each sample location, vegetable samples were collected from three different locations to provide replicate samples of each plant. Vegetable samples were divided into leaf, stem and root. Vegetable samples include spinach, lettuce, cabbage and onion.

\subsection{Digestion of Vegetable Samples for Heavy Metal De- termination}

The vegetable samples were weighed to determine the fresh weight and dried in an oven at $80 \mathrm{C}$ for 72 hours to determine their dry weight. The dry samples were crushed in a mortar and the resulting powder digested by weighing $0.5 \mathrm{~g}$ of oven-dried ground and sieve $(<1 \mathrm{~mm})$ into an acidwashed porclain crucible and placed in a muffle furnancefor four hours at $500^{\circ} \mathrm{C}$. The crucibles were removed from the furnance and cooled. $10 \mathrm{ml}$ of $6 \mathrm{M} \mathrm{HCl}$ was added covered and heated on a steam bath for 15 minute. Another $1 \mathrm{ml}$ of $\mathrm{HNO}_{3}$ was added and evaporated to dryness by continuous heating for one hour to dehydrate silica and completely digest organic compounds. Finally, $5 \mathrm{ml}$ of $6 \mathrm{M} \mathrm{HCl}$ and $10 \mathrm{ml}$ of water were added and the mixture was heated on a steam bath to complete dissolution. The mixture was cooled and filtered through a Whatman no. 541 filter paper into a $50 \mathrm{ml}$ volumetric flask and made up to mark with distilled water.

\subsection{Elemental Analysis of Samples}

Determination of $\mathrm{Pb}, \mathrm{Fe}, \mathrm{Cu}, \mathrm{Zn}, \mathrm{Cd}, \mathrm{Ni}, \mathrm{Mn}$ and $\mathrm{Cr}$ were made directly on each final solution using PerkinElmer Analyst 300 Atomic Absorption Spectroscopy (AAS).

\subsection{Determination of Nitrate, Nitrite, Sulphate and Phos- phate in Vegetable Samples}

Levels of nitrate and nitrite in the vegetable samples solutions were prepared by chopping each sample into smaller sizes. A known amount (1g) of the chopped sample was transferred into $100 \mathrm{ml}$ flask and soaked with $50 \mathrm{ml}$ of distilled water. The flask was capped and shaken for $30 \mathrm{mi}-$ nutes, then filtered into another $100 \mathrm{ml}$ volumetric flask and the volume made to the mark with distilled water [11]. Nitrate was determined spetrophotometrically using standard cadmium reduction method 3649 - SC (Lamotte, 2000), while Nitrite was determined using standard diazotization method 3650 - SC (Lamotte, 2000).

The determination of phosphate in each of the vegetables samples was chopped into small pieces. The chopped samples were then air-dried. The air-dried samples were ground and sieved with a siever of mesh $1 \mathrm{~mm}$. A known amount (1g) of each of the ground and sieved samples was weighed into acid-washed porcelain crucibles. The crucibles were labeled and $5 \mathrm{ml}$ of $20 \%(\mathrm{w} / \mathrm{v})$ magnesium acetate were added and evaporated to dryness. The crucibles were then transferred into the furnace and the temperature was raised to $500^{\circ} \mathrm{C}$. The samples were ashed at this temperature for four (4) hours. Removed and cooled in desiccators.

Ten (10) $\mathrm{ml}$ of $6 \mathrm{M} \mathrm{HCl}$ were then added to each of the crucible and covered, then heated on a steam bath for fifteen minutes. The contents of each crucible were completely transferred into different evaporating basins and $1 \mathrm{ml}$ of concentrated $\mathrm{HNO}_{3}$ was added. The heating was made to continue for 1 hour to dehydrate silica. $1 \mathrm{ml}$ of $6 \mathrm{M} \mathrm{HCl}$ was then added, swirled and then followed by the addition of $10 \mathrm{ml}$-distilled water and again heated on the steam bath to complete dissolution. The contents of the evaporating basins were cooled and then filtered through a Whatman no. 1 filter paper into $50 \mathrm{ml}$ volumetric flasks and the volumes made up to the marks with distilled water [11]. Phosphate was determined using Hach Direct Reading 2000 Spectrophotometer.

For sulphate determination, $5 \mathrm{ml}$ of magnesium nitrate solutions were added to each of the ground and sieved samples in the crucibles. These were then heated to $180^{\circ} \mathrm{C}$ on a hot plate. The heating process was allowed to contin- 
ue until the colour of the samples changed from brown to yellow $[12,13]$. The samples were then transferred to the furnace at a temperature of $500^{\circ} \mathrm{C}$ for four hours. Magnesium nitrate was added to prevent loss of sulphur. The contents of each crucible were carefully transferred to different evaporating basins. $10 \mathrm{ml}$ of concentrated $\mathrm{HCl}$ were added to each of them and covered with watch glasses. They were boiled on a steam bath for 3 minutes. On cooling, $10 \mathrm{ml}$ of distilled water were added to each of the basins and the contents of each were filtered into $50 \mathrm{ml}$ volumetric flasks and the volumes made up to the marks with distilled water [11]. Sulphate was determined using Smart Spectrophotometer (2000).

\section{Results and Discussions}

\subsection{Concentrations of Heavy Metals in Vegetable Sam- ples}

Levels of heavy metals in different parts of vegetable samples (spinach, lettuce, cabbage and onion) from Mirnga and Zira agricultural locations are as presented in Figure 1 and $2 \mathrm{Cr}$ concentrations ranged from 0.23 to $3.22 \mathrm{mg} / \mathrm{kg}$; 0.23 to $3.43 \mathrm{mg} / \mathrm{kg} \mathrm{Mn} ; 0.23$ to $3.45 \mathrm{mg} / \mathrm{kg} \mathrm{Fe} ; 0.21$ to $3.54 \mathrm{mg} / \mathrm{kg} \mathrm{Ni} ; 0.25$ to $4.56 \mathrm{mg} / \mathrm{kg} \mathrm{Pb} ; 0.87$ to $8.34 \mathrm{mg} / \mathrm{kg} \mathrm{Zn}$; 0.34 to $5.44 \mathrm{mg} / \mathrm{kg} \mathrm{Cd}$ and 0.21 to $3.22 \mathrm{mg} / \mathrm{kg} \mathrm{Cu}$. The concentrations of heavy metals in different parts of vegetable samples (spinach, lettuce, cabbage and onion) from Wangaga and Malang agricultural location ranged from 0.10 to $6.22 \mathrm{mg} / \mathrm{kg} \mathrm{Cr} ; 0.11$ to $3.17 \mathrm{mg} / \mathrm{kg} \mathrm{Zn;} 0.10$ to $1.93 \mathrm{mg} / \mathrm{kg} \mathrm{Fe}$; 0.56 to $5.04 \mathrm{mg} / \mathrm{kg} \mathrm{Ni} ; 0.12$ to $0.54 \mathrm{mg} / \mathrm{kg} \mathrm{Pb} ; 0.16$ to $0.90 \mathrm{mg} / \mathrm{kg} \mathrm{Zn;} 0.02$ to $1.23 \mathrm{mg} / \mathrm{kg} \mathrm{Cd}$ and 0.55 to 3.31 $\mathrm{mg} / \mathrm{kg}$ Cu Figure 3 and 4

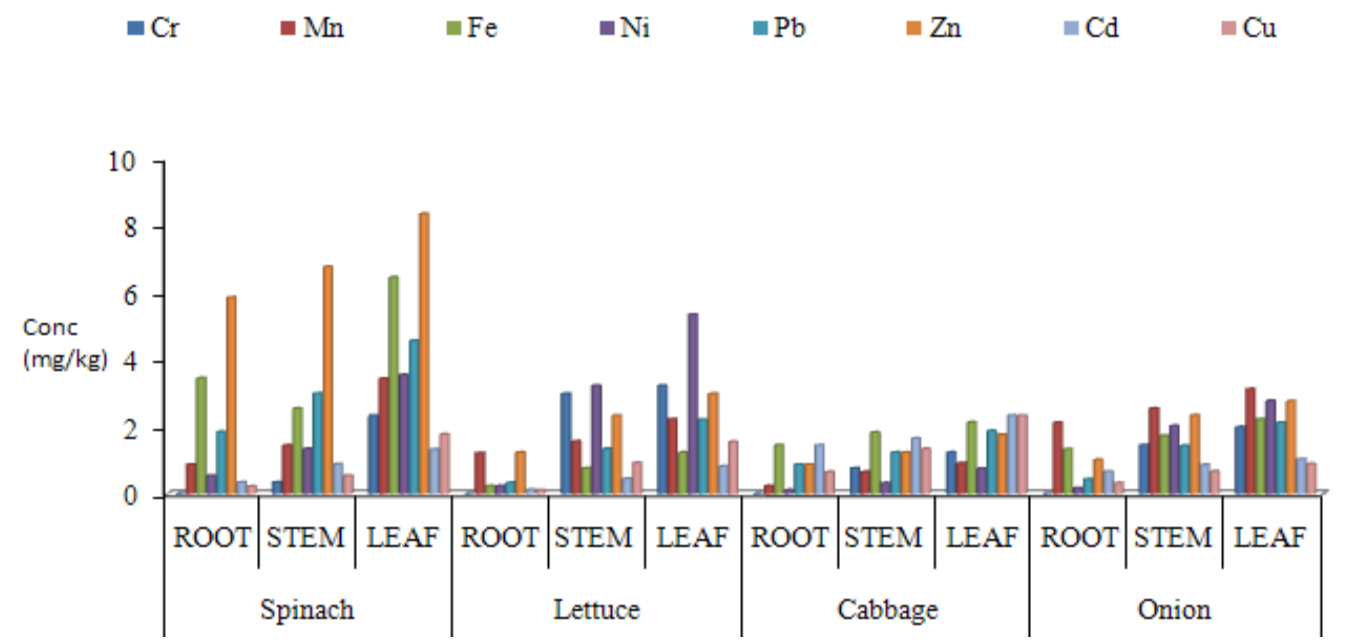

Figure 1. Mean concentrations heavy metals $(\mathrm{Mg} / \mathrm{kg})$ in different parts of vegetable samples (spinach,lettuce, carbage and Onion) from Mirnga agricultural location, Biu, Borno State

$$
\square \mathrm{Cr} \quad \square \mathrm{Mn} \quad \square \mathrm{Fe} \quad \square \mathrm{Ni} \quad \square \mathrm{Pb} \quad \square \mathrm{Zn} \quad \square \mathrm{Cd} \quad \square \mathrm{Cu}
$$

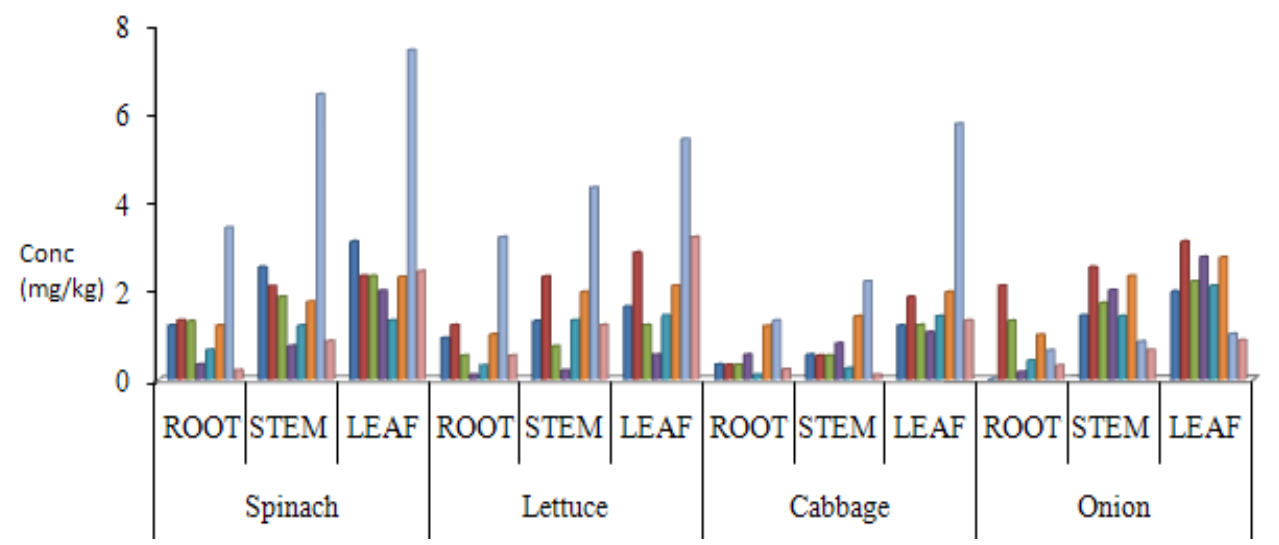

Figure 2. Mean concentrations heavy metals (Mg/kg) in different parts of vegetable samples(spinach, lettuce, carbage and Onion) from Zira agricultural location, Biu, Borno State 


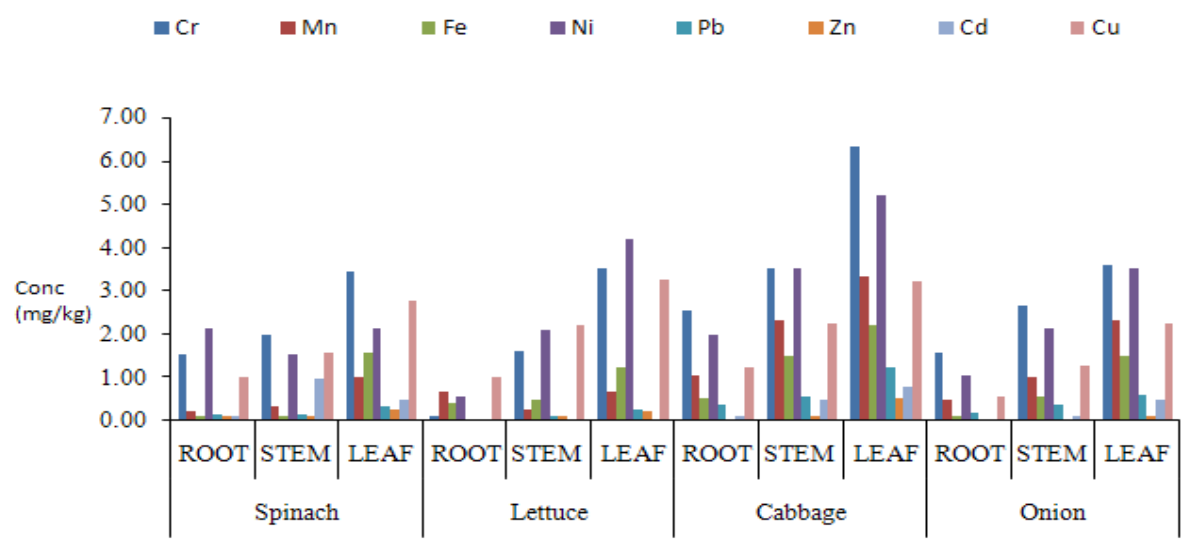

Figure 3. Mean concentrations heavy metals $(\mathrm{Mg} / \mathrm{kg})$ in different parts of vegetable samples (spinach,lettuce, carbage and Onion) from Wangaga agricultural location, Biu, Borno State

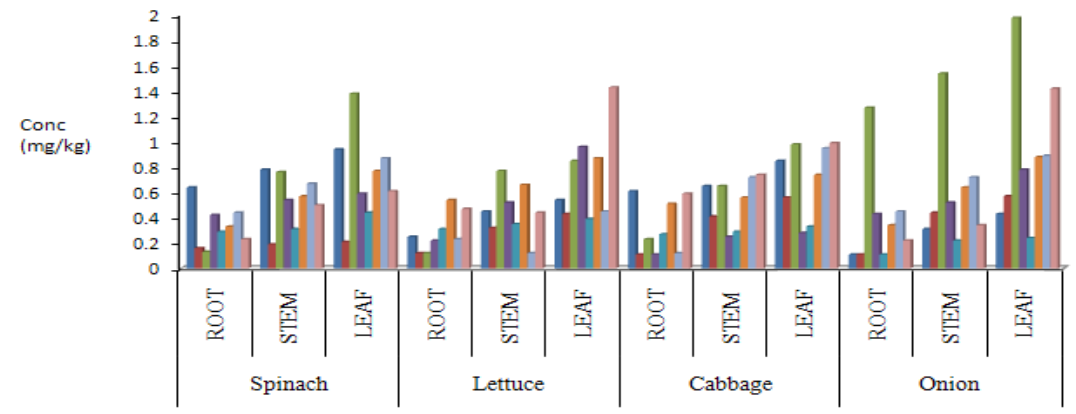

Figure 4. Mean concentrations heavy metals $(\mathrm{Mg} / \mathrm{kg})$ in different parts of vegetable samples (spinach,lettuce, carbage and Onion) from Malang agricultural location, Biu, Borno State

\subsection{Concentrations of Anions in Vegetable Samples}

Figure 5 and 6 present the levels nitrate, nitrite, sulphate and phosphate in different parts of vegetable samples (spinach, lettuce, cabbage and onion) from Mirnga and Zira agricultural location. Nitrate levels ranged from 122.00 to 2132 nitrate $\mathrm{mg} / \mathrm{kg} ; 6.00$ to 48.65 nitrite $\mathrm{mg} / \mathrm{kg} ; 311.00$ to 4321.00 sulphate $\mathrm{mg} / \mathrm{kg}$ and 123.00 to 987 phosphate $\mathrm{mg} / \mathrm{kg}$. The concentrations of some anions nitrate, nitrite, sulphate and phosphate in different parts of vegetable samples (spinach, lettuce, cabbage and onion) from Wangaga and Malang agricultural location is as presented in Figure 7 and 8. Nitrate levels ranged from 87.00 to 2213 nitrate $\mathrm{mg} / \mathrm{kg} ; 8.00$ to 53.00 nitrite $\mathrm{mg} / \mathrm{kg} ; 112.00$ to 4532.00 sulphate $\mathrm{mg} / \mathrm{kg}$ and 22.00 to 1033.00 phosphate $\mathrm{mg} / \mathrm{kg}$.

$$
\text { =NITRATE } \quad \text {-NITRITE } \quad \text { SULPHATE } \quad \text { PHOSPHATE }
$$

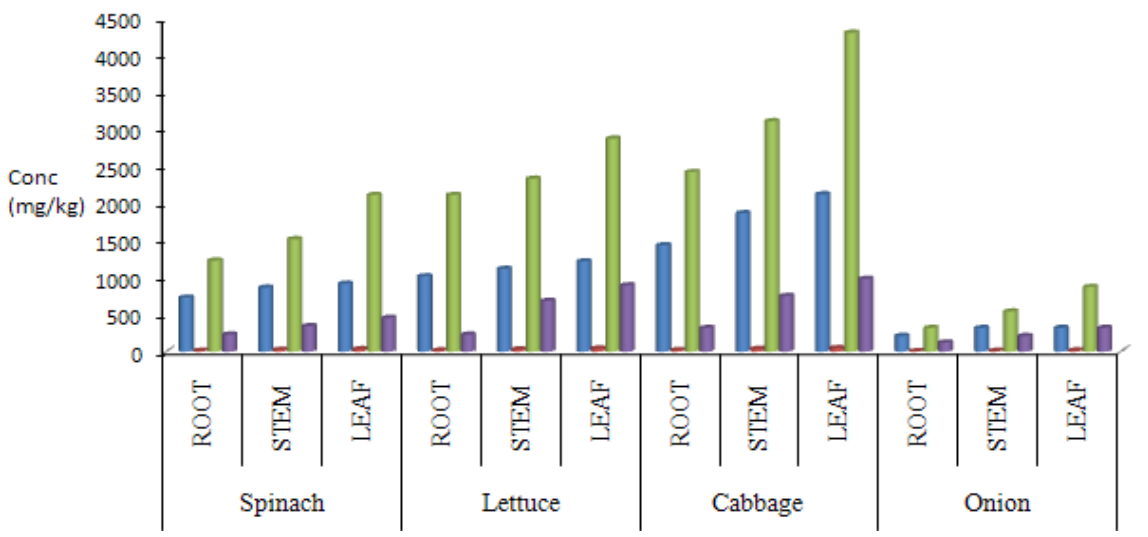

Figure 5. Mean concentrations of nitrate, nitrite, sulphate and phosphate $(\mathrm{Mg} / \mathrm{kg}$ ) in different parts of vegetable samples (spinach, lettuce, carbage and Onion) from Mirnga agricultural location, iu, Borno State 


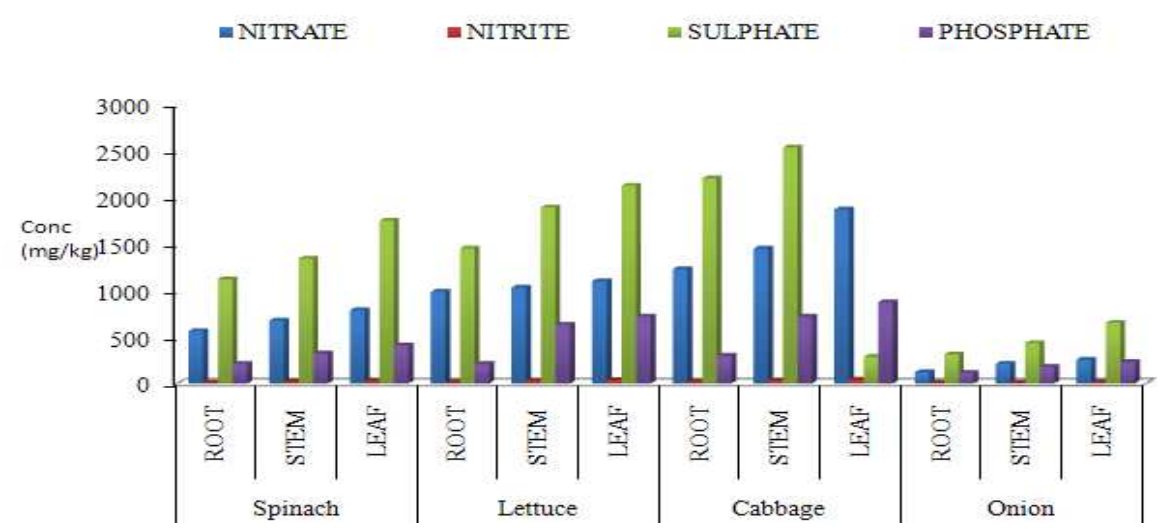

Figure 6. Mean concentrations of nitrate, nitrite, sulphate and phosphate $(\mathrm{Mg} / \mathrm{kg}$ ) in different parts ofegetable samples (spinach,lettuce, carbage and Onion) from Zira agricultural location, Biu, Borno State

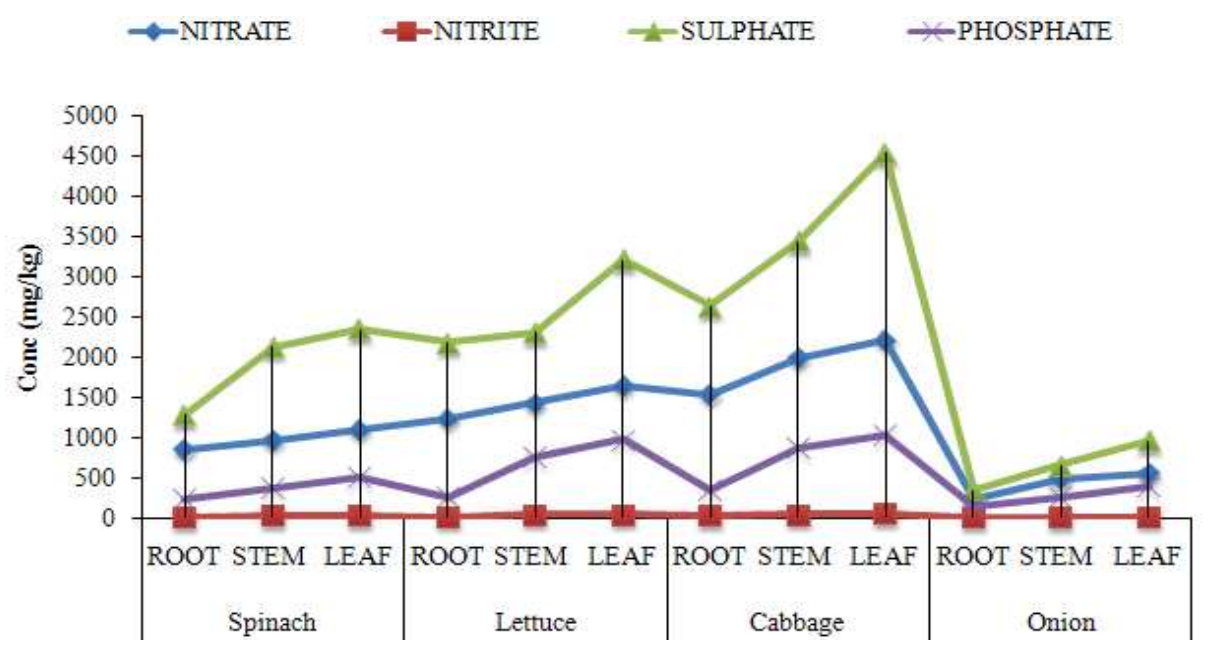

Figure 7. Mean concentrations of nitrate, nitrite, sulphate and phosphate $(\mathrm{Mg} / \mathrm{kg})$ in different parts of vegetable samples (spinach, lettuce, carbage and Onion) from wangaga agricultural location, Bui, Borno State

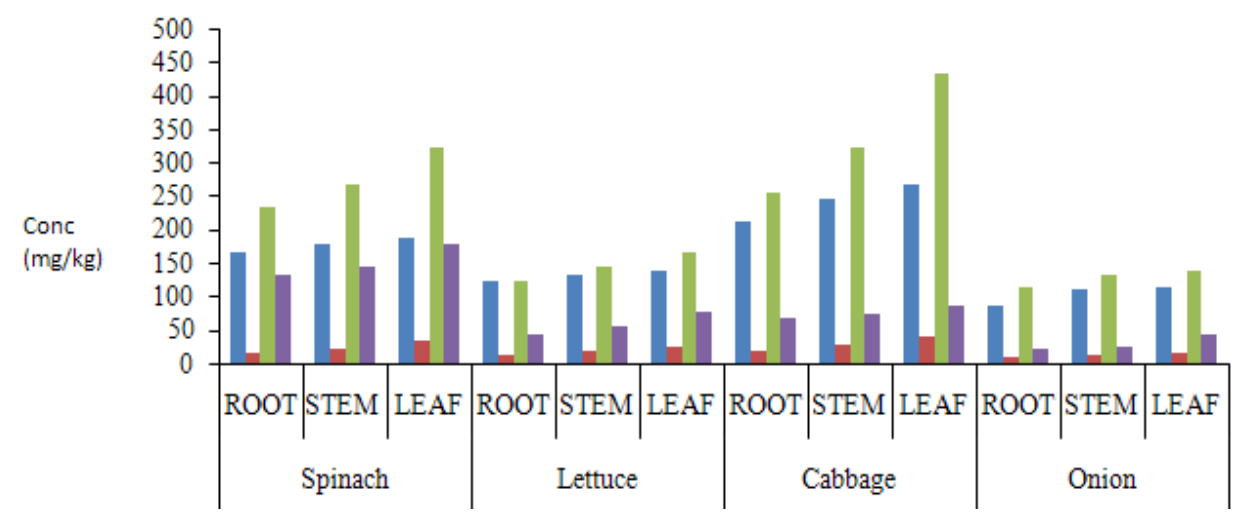

Figure 8. Mean concentrations of nitrate, nitrite, sulphate and phosphate $(\mathrm{Mg} / \mathrm{kg}$ ) in different parts of vegetable samples (spinach, lettuce, carbage and Onion) from Malang agricultural location, Bui, Borno State

In the whole plants studied in the four agricultural locations, leaf contained higher concentrations of heavy metals than roots and stems. Similar study carried out by [14] shows that the heavy metal content of various parts of plant differs. They reported that in vegetables organs the concen- trations of heavy metals are in the order of leaf $>$ stem $>$ root $>$ tuber $>$ bulb $>$ fruit $>$ seed. [15] reported high level of heavy metals $(\mathrm{Pb}, \mathrm{Fe}, \mathrm{Cu}$ and $\mathrm{Zn})$ in their study of the long term effects of municipal waste disposal on soil properties and productivity of sites used for urban agriculture in Abakaliki, 
South Eastern part of Nigeria. [16]studied plant uptake of heavy metals on a similar site at University of Ife dump site and reported that $\mathrm{Pb}$ uptake by water leaf (Talinumtriangulare), okra (Albennucusesculentus) increased in leafs and roots of water leaf and in the fruit of okra relative to those grown in the non-dump sites

The concentrations of heavy metals in all the vegetable samples in the four locations were higher than the $\mathrm{FAO} / \mathrm{WHO}$ guideline values of $0.1-0.2 \mathrm{mg} / \mathrm{kg} \mathrm{Cr}, 0.3$ $\mathrm{mg} / \mathrm{kg} \mathrm{Fe} ; 0.1 \mathrm{mg} / \mathrm{kg} \mathrm{Pb} ; 0.1 \mathrm{mg} / \mathrm{kg} \mathrm{Cu} ; 0.1 \mathrm{mg} / \mathrm{kg} \mathrm{Zn} ; 0.1$ $\mathrm{mg} / \mathrm{kg} \mathrm{Ni} ; 0.02 \mathrm{mg} / \mathrm{kg} \mathrm{Cd}$ and $0.3 \mathrm{mg} / \mathrm{kg} \mathrm{Mn}$. The result of this study agreed with the data reported by [17]. This might be as a results high accumulation of these metals by plant.

The values of nitrate, nitrite, sulphate and phosphate in the vegetable samples show that the leaves are rich in this anion content than other tissues studied. Similar study was carried out by [14] stated that nitrate and nitrite content of various parts of a plant differs in the order of leaf $>$ stem $>$ root $>$ tuber $>$ bulb $>$ fruit $>$ seed. [18] reported that vegetables that are consumed with their roots, stems and leaves have a high nitrate and nitrite accumulation, whereas melons and those vegetables with only fruits as consumable parts have a low nitrate accumulation This observation was also noted by [19], where leaf and stem accumulate the most nitrate, sulphate and nitrite followed by stem and roots [20] in their study; "Nitrate and nitrite accumulation in vegetables", noted that leafy vegetables such as spinach, cabbage and lettuce contains nitrate, sulphate and nitrite at significant levels. Result from this study agreed with the above observations, in that levels of nitrate, sulphate, nitrite and phosphate were higher in spinach, cabbage and lettuce within the four agricultural locations. [20]also noted that plants that develop fruits or storage tissues, such as potato and tomato, usually have low nitrite and nitrate concentrations. In the present study the concentrations of these anions were higher in cabbage, lettuce and spinach samples, while onion shows the least levels. Nitrite content in vegetables is usually very low compared to nitrate [19]. This was also in agreement with the present study. Result of analysis of variance (ANOVA) showed that variation between vegetables and organs were statistically significant $(p<0.05)$. The fact that concentrations of nitrate and nitrite in the vegetables varied between the four sample areas could be attributed to differences in anthropogenic activities, like different farming practices such as excessive usage of fertilizers, herbicides and other agrochemicals [20, $21]$, as well as the use of waste water and all kinds of polluted water in irrigating the vegetables in these areas. This could also be attributed to a number of environmental factors such as drought, day light intensity, and soil temperature and soil type [22, 23].

\section{Conclusion}

In the whole plants studied from the four agricultural locations leaf contained higher concentrations of heavy metals than roots and stems. The results also indicate that all the vegetable samples analyzed in this study had high levels of heavy metals and anions. The levels of all the metals studied were higher than those recommended by Food and Agricultural Organization (FAO) and the $\mathrm{WHO} / \mathrm{EU}$ joint limits of $0.1-0.2 \mu \mathrm{g} / \mathrm{g} \mathrm{Cr}, 0.3 \mu \mathrm{g} / \mathrm{g} \mathrm{Fe} ; 0.1 \mu \mathrm{g} / \mathrm{g} \mathrm{Pb} ; 0.1 \mu \mathrm{g} / \mathrm{g}$ $\mathrm{Cu} ; 0.1 \mu \mathrm{g} / \mathrm{g} \mathrm{Zn} ; 0.1 \mu \mathrm{g} / \mathrm{g} \mathrm{Ni} ; 0.02 \mu \mathrm{g} / \mathrm{g}$ Cd and $0.3 \mu \mathrm{g} / \mathrm{g}$ Mn.The high levels of these heavy metals place the consumers of these vegetable crops grown within the study area at health risk with time unless an urgent step is taken by relevant agencies in address this issue.

\section{Refernces}

[1] A.I.Ihekeronye, andP.O. Ngoddy, "Integral Food Science and technology for the Tropics.Macmillian Education Ltd. Oxford and London," p 293, 1985.

[2] K.A. Yusuf, and S.O. Oluwole, "Heavy metal (Cu, Zn, Pb) contamination of vegetables in urban city: A case study in Lagos,"Research Journal of Environmental Science, vol. 30, pp. 292-298 2009.

[3] O. Sukreeyapongse, S. Panichsakpatana, and H. Hansen, "Transfer of heavy metals from sludge amended soil to vegetables and leachates" Paper Presented at the 17th World Congress of Soil Science (WCSS), 14th - 21st August 2002, Thailand. Symposium No 29, Paper No. 1969, 2002.

[4] M.A.Radwan, and A.K. Salama, "Market basket survey for some heavy metals in Egyptian fruits and vegetables,"Food and Chemical Toxicology, vol. 44, no. 8, pp. 1273-1278, 2006.

[5] S.Khan, Q. Cao, Y.M. Zheng, Y.Z. Huang, and Y.G. Zhu, "Health risk of heavy metals in contaminated soils and food crops irrigated with waste water in Beijing, China,"EnvironmentalPollution, vol. 152, no. 3, pp. 686-692, 2008.

[6] C.S.C.Wong, X.D. Li, G. Zhang, S.H. Qi, and X.Z. Peng, "Atmospheric depositions of heavy metals in the Pearl River Delta, China," Atmospheric Environment, vol. 37, pp. 767776, 2003.

[7] A. Singh, R.K. Sharma, M. Agrawal, and F.M. Marshall, "Risk assessment of heavy metal toxicity through contaminated vegetables from waste water irrigated area of Varanasi, India,” Tropical Ecology, vol. 51, pp. 375-387, 2010.

[8] R.K.Sharma, M. Agrawal, and F.M. Marshall, "Heavy metal $(\mathrm{Cu}, \mathrm{Zn}, \mathrm{Cd}$ and $\mathrm{Pb})$ contamination of vegetables in urban India: A case study in Varanasi," Environmental Pollution, vol. pp. 154: 254-263, 2008a.

[9] R.K. Sharma, M. Agrawal, and F.M. Marshall, "Atmospheric deposition of heavy metals $(\mathrm{Cu}, \mathrm{Zn}, \mathrm{Cd}$ and $\mathrm{Pb})$ in Varanasi City, India,'Environmental Monitory Assessement, vol. 142, pp. 269-278, 2008 b.

[10] W. Haiyan, and A.O. Stuanes, "Heavy metal pollution in airwater-soil-plant system of zhuzhou city, hunan province, china,"Water Air and Soil Pollutution, vol.147, pp. 79-107, 2003.

[11] [11]M.Radojevic, and V.N.Bashkin, "Practical Environmental Analysis. The Royal Society Of Chemistry, Cambridge," p 466, 1999 
[12] AOAC."Official methods of analysis of the Association of Official Analytical Chemists.14th ed.Arlington, VA: The Association of Official Analytical Chemists, Inc," pp. 444 453, 1994.

[13] AOAC."Official methods of analysis ofthe Association of Official Analytical Chemists.Alexandria, VA: Association of Official Analytical Chemists," pp.432-444, 1998.

[14] Santamaria, A. Elia, F. Serio, and E. Todaro, "A suevey of nitrate, metals and oxalate content inretail fresh vegetables,"Journal of Science Foodand Agriculture, vol. 79,pp. 1882-1888.1999.

[15] M.A.N.Anikwe, and K.C.A.Nwobodo, "Long term effect of municipal waste disposalon soil properties and productivity of sites used for urban agriculture in Abakaliki, Nigeria,"Bioresources Technology, vol. 83, pp. 241-251, 2006.

[16] C.M.A. Ademoroti, "Standard method for water and Effluents Analysis. Foludex pressLtd, Ibadan," pp.22-23, 44-54, 111-112, 1996.

[17] S. Kocak, O. Tokusoglu, and S. Aycan, "Some heavy metal and trace essential elementdetection in canned vegetable foodstuffs by differential pulse polarography (DPP),"Electronic Journal of Environment and Agriculture and Food Chemistry,vol. 4, pp. 871-878, 2005.
[18] Z. Y.Zhou, M. J. Wang, and J. S Wang, "Nitrate and nitrite contamination in vegetables inChina," Food Reviews International, vol. 16, pp. 61-76, 2000.

[19] J. Hunt, and M. K. Turner, "A survey of nitrite concentrations in retail fresh vegetables,"Food Additive and Contaminations.vol. 11, no. 3, pp. 327-332, 1994.

[20] D. N. Maynard, Barker, A. V. Minotti, and N. H. Peck, "Nitrate accumulation in vegetables,"Journal of Advance.Agronomy, vol.28, pp.71-118, 1978.

[21] D. J. Cantliffe, "Nitrate accumulation in table beets and spinach as affected by nitrogen,phosphorous, and potassium nutrition and light intensity,"Agronomy Journal, vol. 65, pp. 563- 565, 1973b

[22] S. D. Gangolli, P. A. Van Den Brandt, V. Feron, J. C. Janzowsky, J. H. Koeman, G. J. Speijers, A. Spiegelhalder,R. Walker, and J. S. Wishnok, "Assessment: nitrate, nitrite and N-nitrosocompounds,"European Journal of Pharmacology Environmental Toxicology andPharmacology, vol. 4, no. 1, pp. 1-38, 1994.

[23] FAO/WHO, "Evaluation of certain food Additives and Contaminants. Geneva, WorldHealth Organization, Joint FAO/WHO Expert Committee on Food Additives, World Health OrganizationTechnical Report Series,"vol 859, pp.29-35, 1995. 